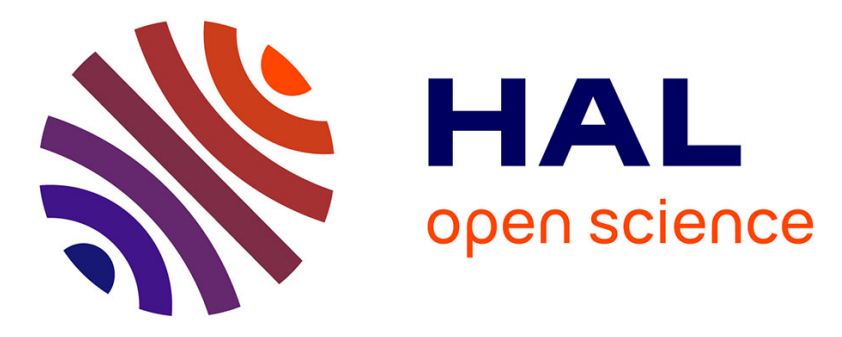

\title{
Dendrochemical patterns of calcium, zinc, and potassium related to internal factors detected by energy dispersive X-ray fluorescence (EDXRF)
}

Kevin T. Smith, Jean Christophe Balouet, Walter C. Shortle, Michel Chalot, Francois Beaujard, Håkan Grudd, Don A. Vroblesky, Joel G. Burken

\section{To cite this version:}

Kevin T. Smith, Jean Christophe Balouet, Walter C. Shortle, Michel Chalot, Francois Beaujard, et al.. Dendrochemical patterns of calcium, zinc, and potassium related to internal factors detected by energy dispersive X-ray fluorescence (EDXRF). Chemosphere, 2014, 95, pp.58-62. 10.1016/j.chemosphere.2013.08.017 . hal-01189763

\section{HAL Id: hal-01189763 \\ https://hal.science/hal-01189763}

Submitted on 27 May 2020

HAL is a multi-disciplinary open access archive for the deposit and dissemination of scientific research documents, whether they are published or not. The documents may come from teaching and research institutions in France or abroad, or from public or private research centers.
L'archive ouverte pluridisciplinaire HAL, est destinée au dépôt et à la diffusion de documents scientifiques de niveau recherche, publiés ou non, émanant des établissements d'enseignement et de recherche français ou étrangers, des laboratoires publics ou privés. 


\title{
Dendrochemical patterns of calcium, zinc, and potassium related to internal factors detected by energy dispersive X-ray fluorescence (EDXRF)
}

\author{
Kevin T. Smith ${ }^{\mathrm{a}, *}$, Jean Christophe Balouet ${ }^{\mathrm{b}}$, Walter C. Shortle ${ }^{\mathrm{a}}$, Michel Chalot ${ }^{\mathrm{c}, \mathrm{d}}$, François Beaujard ${ }^{\mathrm{e}}$, \\ Håkan Grudd $^{\mathrm{f}}$, Don A. Vroblesky ${ }^{\mathrm{g}}$, Joel G. Burken ${ }^{\mathrm{h}}$ \\ ${ }^{a}$ Northern Research Station, USDA Forest Service, 271 Mast Road, Durham, NH 03824, United States \\ ${ }^{\mathrm{b}}$ Environment International, 2 ruelle du Hamet, 60129 Orrouy, France \\ ${ }^{\mathrm{c}}$ Laboratoire Chrono-Environnement, Université de Franche-Comté, 4 place Tharradin, BP 71427, 25211 Montbelieard, France \\ ${ }^{\mathrm{d}}$ Université de Lorraine, Faculté des Sciences E Technologies, 54506 Vandoeuvre-les-Nancy Cedex, France \\ e UMR 547 PIAF, INRA-UBP, Site de Crouel, 5 chemin de Beaulie, 63039 Clermont-Ferrand Cedex 02, France \\ ${ }^{\mathrm{f}}$ Bolin Centre for Climate Research, Department of Physical Geography and Quaternary Geology, Stockholm University, SE-106 91 Stockholm, Sweden \\ ${ }^{\mathrm{g}}$ U.S. Geological Survey, Columbia, SC 29210, United States \\ ${ }^{\mathrm{h}}$ Missouri University of Science and Technology, Rolla, MO 65409, United States
}

\section{H I G H L I G H T S}

-We use EDXRF to identify trends in high-resolution cation distribution in tree rings.

- Potassium counts are elevated in sapwood and infected wood.

- Localized peaks in calcium counts can be associated with crystals in wood.

- Intra-annual variation in peak counts appears associated with ring boundaries.

\section{A R T I C L E I N F O}

\section{Article history:}

Received 22 April 2013

Received in revised form 5 August 2013

Accepted 7 August 2013

Available online 10 September 2013

\section{Keywords:}

Dendrochemistry

Cation distribution

Wood calcium

Wood potassium

\begin{abstract}
A B S T R A C T
Energy dispersive X-ray fluorescence (EDXRF) provides highly sensitive and precise spatial resolution of cation content in individual annual growth rings in trees. The sensitivity and precision have prompted successful applications to forensic dendrochemistry and the timing of environmental releases of contaminants. These applications have highlighted the need to distinguish dendrochemical effects of internal processes from environmental contamination. Calcium, potassium, and zinc are three marker cations that illustrate the influence of these processes. We found changes in cation chemistry in tree rings potentially due to biomineralization, development of cracks or checks, heartwood/sapwood differentiation, intraannual processes, and compartmentalization of infection. Distinguishing internal from external processes that affect dendrochemistry will enhance the value of EDXRF for both physiological and forensic investigations.
\end{abstract}

Published by Elsevier Ltd.

\section{Introduction}

Dendrochemistry is the chemical analysis and interpretation of precisely dated tree rings. Interpretation of dendrochemical patterns begins with an understanding of wood structure and function. In cross-section, the wood of a mature stem of many familiar

\footnotetext{
* Corresponding author. Tel.: +1 603868 7624; fax: +1 6038687604 .

E-mail addresses: ktsmith@fs.fed.us (K.T. Smith), balouet.jean-christophe@ neuf.fr (J.C. Balouet), wshortle@fs.fed.us (W.C. Shortle), michel.chalot@univ-fcomte. fr (M. Chalot), francois.beaujard@clermont.inra.fr (F. Beaujard), hakan.grudd@ natgeo.su.se (H. Grudd), vroblesk@usgs.gov (D.A. Vroblesky), burken@mst.edu (J.G. Burken).
}

conifer and ring-porous tree species appears as an outer band of sapwood and an inner core of heartwood (Shigo and Hillis, 1973). All wood begins as sapwood, differentiated secondary xylem produced by mitosis of the vascular cambium. Most of the volume of sapwood consists of thick-walled tracheid and/or vessel cells. Tracheid and vessel differentiation involves programmed cell death that opens the cell lumens for bulk conduction of water and dissolved elements (Carlquist, 2010). The conduction pathway consisting of the cell wall system and open lumens of conducting cells is termed the apoplast. The critical defining characteristic of sapwood is the presence of both the apoplast and symplast, the latter being the network of living cell contents mostly contained in small, thin-walled parenchyma cells (Shigo and Hillis, 1973). In 
heartwood-forming species, as new rings of sapwood are added to the perimeter of the mature stem cylinder, rings of older sapwood are converted into heartwood. Heartwood conversion consists of the withdrawal of the symplast including the removal of cytoplasmic nitrogen $(\mathrm{N})$, phosphorous $(\mathrm{P})$, and potassium $(\mathrm{K})$ (Meerts, 2002), the cessation of water conduction in the xylem, and frequently the deposition of organic compounds that confer some degree of decay resistance (Shigo and Hillis, 1973).

Trends of cation distribution in the stemwood of living trees result from the interaction of tree physiology and external environmental conditions. Various analytical methods have been used to identify internal physiological and pathological processes in wood that affect cation concentration (Smith and Shortle, 1996). High resolution chemical analysis of precisely dated tree-ring series provides the opportunity to better understand these naturally occurring interactions. The objective of this research is to identify naturally occurring processes in trees such as maturation and infection that affect distribution of $\mathrm{K}$, calcium (Ca), and zinc ( $\mathrm{Zn}$ ) cations along the radial vectors of tree rings collected as increment cores. Determination of the effects of normal internal biological processes will improve the reliability of detection for releases of environmental contaminants.

The elements $\mathrm{Ca}, \mathrm{K}$, and $\mathrm{Zn}$ are essential for plant nutrition and generally enter the tree translocation system as cations. Within plant tissues, a small amount of Ca occurs in the cell membrane and cytoplasm, while the bulk of Ca crosslinks the structural polymers of plant cell walls (Pilbeam and Morley, 2006). Most Ca translocation occurs through the apoplast and follows a Donnan equilibrium model (Momoshima and Bondietti, 1990). Unlike Ca, $\mathrm{K}$ functions to regulate osmotic and electrochemical gradients as well as enzyme activity rather than for mechanical structure and is actively accumulated and transported within the symplast. Homeostatic regulation of cytoplasmic $\mathrm{K}$ is likely through the storage and utilization of $\mathrm{K}$ from vacuolar storage (Mengel, 2006). As with $\mathrm{Ca}$ and $\mathrm{K}, \mathrm{Zn}$ is essential for metabolism and enters the tree root system as a divalent cation and is translocated as the cation or as an organic complex (Krämer, 2010) through both symplastic and apoplastic pathways (Storey, 2006; Broadley et al., 2007). Unlike Ca which in nature readily associates with the oxyanions of organic acids, $\mathrm{Zn}$ is frequently chelated with sulfhydryl groups of organic compounds such as phytochelatins (Tennstedt et al., 2009). All classes of enzymes contain members with an absolute requirement for $\mathrm{Zn}$ to provide the catalytic center or spatial conformation for enzymatic activity (Broadley et al., 2007).

Early research on the inorganic chemistry of wood analyzed acid digests of bulk samples of wood ash as a potential commercial source for K fertilizer (Forest Products Laboratory, 1919). That research on wood ash did not consider wood position along the stem radius as a source of variation in $\mathrm{K}$ concentration. Improved analytic sensitivity permitted element determination from the ashing or the direct acid digestion of smaller samples of wood contained in a few tree-rings or in localized layers associated with the tree wound response (Safford et al., 1974; Smith and Houston, 1994). These improvements increased spatial resolution and the potential to increase temporal resolution with respect to the concentration of $\mathrm{K}$ and other elements in the year of ring formation. More mild extraction techniques (e.g., Minocha and Shortle, 1993) provided the opportunity to explore the bioavailability as well as the total concentration of inorganic elements.

More recently, non-destructive analysis of wood has demonstrated the potential to sample across very short physical distances with concurrent chemical analysis of multiple ions within a single annual growth ring. At this level of temporal precision and high sensitivity, intra-annual trends in cation dendrochemistry are observable. Techniques that do not require digestion or extraction of samples include proton induced X-ray emission (PIXE; McClena- hen et al., 1989) and scanning X-ray fluorescence microscopy (SXFM: Pearson et al., 2011). However, both PIXE and SXFM are limited in availability due to their requirement for a particle accelerator to generate the protons or appropriate X-ray radiation. The sensitive high-resolution EDXRF technique is increasingly available and appealing from the perspective of understanding tree physiological processes and for forensic dendrochemistry at sites characterized by cation concentrations that exceed ambient levels (Smith et al., 2008; Balouet et al., 2009). In a recent study, EDXRF of chlorine in tree rings was used to identify multiple releases of chlorinated hydrocarbon solvents (Balouet et al., 2012). In this report, patterns of $\mathrm{Ca}, \mathrm{Zn}$, and $\mathrm{K}$ are described and attributed to internal processes of maturation, allocation, and infection.

\section{Methods}

\subsection{Sample collection and measurement}

Visual and numerical data presented in this report were drawn from several recent investigations by Pollution Investigation by Trees (PIT), an international research program funded by ADEME, the French Environment \& Energy Management Agency. The data were obtained from trees in France, Sweden, and the United States.

In all cases increment cores (10-mm diameter) were extracted from living trees and air-dried as they were collected. Dried cores were mounted into grooved wooden blocks and surfaced with a graded series of silicon carbide sandpaper $(50,100,200$, and 400 grit). The sanded cores were screened under low-powered magnification to detect obvious wounds, infections, or other features with the potential to affect chemical analysis. All further sample processing and analysis was conducted at a constant $20^{\circ} \mathrm{C}$ and $50 \%$ relative humidity at the Dendrolab of the University of Stockholm. A sample lath (2 mm thick) was cut from the full length of each mounted core, parallel to the transverse wood surface. Laths were mounted vertically in the Itrax Multiscanner [Cox Analytical Systems, Molndal, Sweden] fitted with a $1.9 \mathrm{~kW}$ Cr-tube X-ray source and silicon drift chamber detector (SDD). The collimator system within the SDD defined the irradiated spot on the transverse surface of the sample at $0.05 \times 4 \mathrm{~mm}$ (radial:tangential) with an exposure time of $10 \mathrm{~s}$ per spot. In addition to the SDD which detected X-ray fluorescence, a second detector simultaneously intercepted transmitted X-rays to produce a density image or radiogram similar to an X-ray film.

The sample was advanced in $50-\mu \mathrm{m}$ increments along the radial plane. The series of counts along the irradiated length of the sample was normalized for matrix/density effects and smoothed using a time-weighted centered moving average (Balouet et al., 2009) and plotted by spot position along the core radiogram. The precise relationship of counts to cation concentration is not necessarily linear throughout the detectable range of $\mathrm{Ca}, \mathrm{K}$, and $\mathrm{Zn}$ concentration and can vary with tree species and analytical conditions. Trends in the plotted counts do correspond to qualitative trends in element concentration.

\subsection{Data presentation}

The grayscale radiograms produced by EDXRF analysis show the boundaries of annual rings. The comparatively less-dense earlywood of conifers appears darker in the image while the more dense latewood appears lighter due to the greater absorbance and reduced transmission of X-rays as wood density increases. Such imaging is the opposite of optical images in which the less dense earlywood reflects more visible light and appears lighter in color than the more dense and visually darker latewood. For species with wide rays such as in oak (Quercus spp.), the rays appear as straight 
or wavy light-gray lines extending more-or-less along the length of the core sample, essentially following the radius of the sample stem. Although consisting of the same cell types with similar intrinsic density (Wiedenhoeft, 2010), the orientation of rays results in more cell wall material exposed to block X-rays from reaching the detector. The staggered anatomical alignment of ray plates, the eccentric growth of many tree stems, and an oblique angle of sample boring results in some deviation from a strictly radial orientation. Although present, comparatively narrow rays of conifers and diffuse-porous broadleaved trees are usually not discernible in the radiograms.

\section{Results and discussion}

\subsection{Biomineralization}

Biomineralization is the term used here for the formation or accumulation of minerals by organisms into biological structures or their immediate environment. Areas of high mineral content such as precipitated crystals block X-ray transmission through the sample and appear light gray or white in the radiogram. In Fig. 1 of a sample from silver poplar (Populus alba), the white flecks in the wood formed in 1996 and 1999 are associated with peak concentrations in Ca. The white flecks are similar in appearance to those previously described as calcium carbonate crystals from radiograms of $P$. trichocarpa and $P$. robusta (Janin and Clément, $1972,1973)$. The flecks as measured using the $50-\mu \mathrm{m}$ traverse increments in Itrax are also similar in size to those previously reported. Smaller calcium crystals were also observed in radiograms of pedunculate oak (Quercus robur, also known as Q. pedunculata) and attributed to calcium oxalate on the basis of crystal shape (Vansteenkiste et al., 2007). Calcium oxalate is one of the most common biominerals in forest vegetation and forest soils, produced by both plants and fungi (Verrechia et al., 2006; Smith et al., 2009) and observed in poplar (Todeschini et al., 2011). However, peak Ca concentrations also occur independently of putative crystals observed in the radiogram. Peak Ca concentrations in the apparent absence of crystal formation could be associated with increased numbers of ionic binding sites in the wood cell walls or

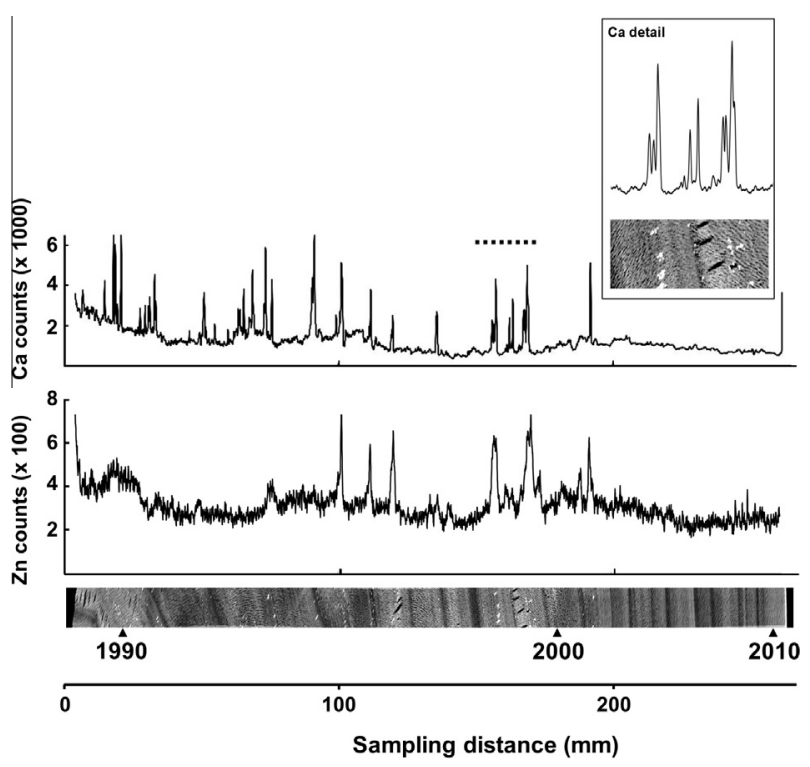

Fig. 1. Radiogram and EDXRF counts of $\mathrm{Ca}$ and $\mathrm{Zn}$ in silver poplar (Populus alba) from New Haven, Missouri, USA. The dotted line indicates the sample position within the 1999 growth ring and the inset detail which shows white flecks suggestive of Ca crystals and black streaks consistent with drying checks. increased sap pH (Momoshima and Bondietti 1990). Previous studies have associated marked increases in $\mathrm{Ca}$ and $\mathrm{Zn}$ or $\mathrm{Ca}$ alone with shifts in carbohydrate polymer formation associated with cellular stress (Pirkkalainen et al., 2012) and formation of compartmentalization boundaries following injury and infection (Shevenell and Shortle 1986).

Highly localized areas of peak $\mathrm{Zn}$ concentration were also occasionally observed (Fig. 1), both coincident with and independent of $\mathrm{Ca}$ peaks. Unlike $\mathrm{Ca}$, these peaks were independent of opaque inclusions in the Itrax radiograms. Although both $\mathrm{Ca}$ and $\mathrm{Zn}$ can form essentially insoluble carbonate and oxalate salts, we find no documentation of the biomineralization of $\mathrm{Zn}$ crystals in wood. Interestingly, Zn-treatment increased the formation of Ca oxalate crystals in poplar without the incorporation of $\mathrm{Zn}$ into the crystals, suggesting that $\mathrm{Zn}$ displaced Ca from some binding or accumulation sites in the cells (Todeschini et al., 2011).

\subsection{Sample checks or cracks}

Physical anomalies in the sample are important to recognize because they can affect the data obtained by EDXRF. Drying checks or cracks in the sample allow radiation during EDXRF to pass unimpeded and appear dark in the radiogram. Cracks may be present in the tree prior to sampling or may occur during the sampling process and can be identified during initial screening. The black streaks in the 1996 ring (Fig. 1) are consistent with drying checks in the core. Wood in living trees is generally at or above the fiber saturation point in moisture content. Due to the anisotropic structure of wood, drying results in wood shrinkage to a greater degree in the tangential than the radial plane. Lenticular cracks or surface checks form to relieve the tension from wood shrinkage. Generally, checks occur from the outer surface of the sample inward, but the combination of visual assessment and the chemical profile would likely resolve more anomalies than either operation done separately.

\subsection{Tissue and intrannual patterns of $K$}

The high mobility and electrolytic characteristics of $\mathrm{K}$ stimulated development of electrical characterization of wood maturation and infection (Ostrofsky and Shortle, 1989). The typical differentiation of heartwood and sapwood by $\mathrm{K}$ concentration is shown in Fig. 2 of pedunculate oak (Quercus robur). The common pattern in a healthy oak is for the sapwood to have a relatively high concentration of $\mathrm{K}$ and for the heartwood to have a much lower concentration consistent with the metabolic role of $\mathrm{K}$ and high $\mathrm{xy}-$ lem mobility (Penninckx et al., 2001). Superimposed on this pat-

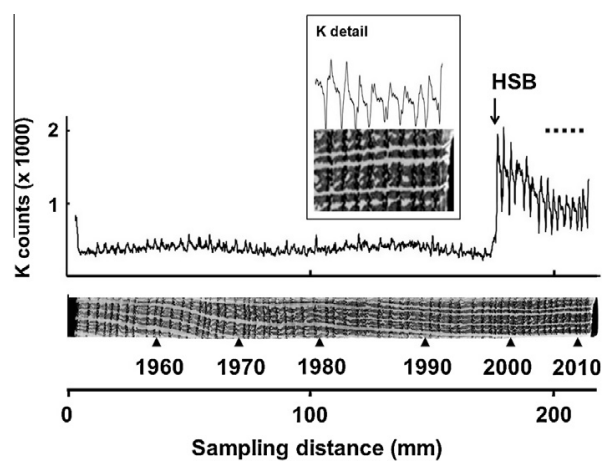

Fig. 2. Radiogram and $K$ counts in pedunculate oak (Quercus robur) from Compiègne Forest, France. The position of the heartwood/sapwood boundary (HSB) is marked. The dotted line indicates the sample position of the inset enlargement which shows repeated intrannual variation in $\mathrm{K}$ concentration. 


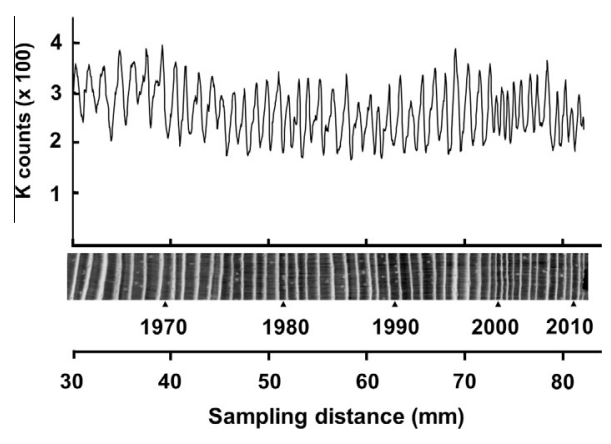

Fig. 3. Radiogram and $\mathrm{K}$ counts in a sample of pine (Pinus sylvestris) from Swedish Lapland showing repeated intra-annual variation in $\mathrm{K}$ concentration. The white spots within the grow rings are resin canals, a constitutive feature in the wood of his species.

tern of elevated concentration of $\mathrm{K}$ in sapwood is an intra-annual pattern of locally high counts of $\mathrm{K}$ in the in the earliest-formed portion of the wide band of oak latewood (Fig. 2). If only strongly ringporous samples were examined, the valleys may mistakenly be attributed to open lumens in the large vessels and the peaks attributed to relatively element-rich bands of parenchyma. However, an intrannual peak of $\mathrm{K}$ also occurs in the narrow band of latewood in Fig. 3 of Scots pine (Pinus sylvestris). The intra-annual variations of other elements do not show a consistent relationship with respect to tissue or cell type. Although not yet resolved, this intra-annual pattern may be due to cell-to-cell differences in the microfibril angle of cellulose and affect results obtained by X-ray fluorescent analysis (Pirkkalainen et al., 2012).

\subsection{Compartmentalization and infection}

Fig. 4 of willow (Salix alba) shows the effect of injury and infection on K concentration. Willow, maple (Acer sp.), birch (Betula sp.) as well as some other diffuse porous hardwoods do not produce heartwood (Section 3.3) as a result of wood maturation (Shigo and Hillis, 1973; Wiedenhoeft, 2010). However, a darker core of wound-initiated discoloration (WID) in these trees results from wounding, infection, and tree defense processes. WID generally forms within the constitutive and induced boundaries of compartmentalization that resist the spread of infection and loss of function (Shortle, 1979; Smith, 2006). The WID can pass through several stages of moisture content and ion concentration (Shortle et al., 1996) prior to physical degradation of the wood cell walls. The sapwood in wood formed from 1996 to 2011 is characteristically high in K concentration. Wood formed in 1982-1995 is in the early stage of WID formation with low $\mathrm{K}$ concentration and a slightly darker appearance in an optical image (not shown). Concentration of $\mathrm{K}$ increases as WID progresses in wood formed in

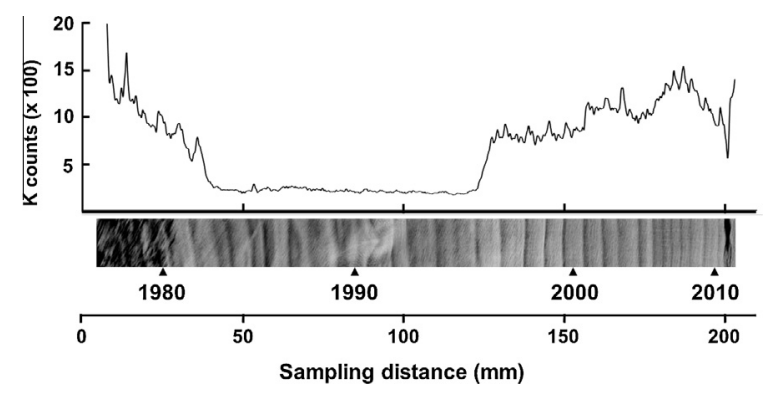

Fig. 4. Radiogram and $\mathrm{K}$ counts of willow (Salix alba) from Ploufragan, France showing elevated $\mathrm{K}$ in sapwood, advanced wound-initiated discoloration, and decayed wood.
1980-1982 and continues high in wood formed earlier which contains advanced decay. Advanced decay is indicated as darker rings (less X-ray dense) in the radiogram. The elevated $\mathrm{K}$ in the decayed wood of Fig. 4 is consistent with infection of the wood by microorganisms as demonstrated in both laboratory (Ostrofsky et al., 1997) and field studies (Shortle and Smith, 1987). This increase in mobile cations is the basis for electrical resistivity methods to detect internal infection (Ostrofsky and Shortle, 1989).

\section{Conclusions}

Dendrochemical patterns were detected in tree cores by EDXRF line scanning at a $50-\mu \mathrm{m}$ resolution. The dendrochemical patterns of $\mathrm{Ca}, \mathrm{Zn}$, and $\mathrm{K}$ can identify physiological and anatomical processes within the tree. Such processes include biomineralization, development of cracks or checks, heartwood/sapwood differentiation, intra-annual processes, and compartmentalization of injury and infection. Identification of these processes supports the proper interpretation of tree ring chemistry as a record of past environmental contamination events. Alignment of EDXRF elemental profiles and radiographs allows visualization of dendrochemical trends and potentially distinguishes internal physiological, anatomical, and pathology effects on tree-ring chemistry from external environmental events such as pollution impacts.

\section{References}

Balouet, J.C., Burken, J.G., Karg, F., Vroblesky, D., Smith, K.T., Grudd, H., Rindby, A., Beaujard, F., Chalot, M., 2012. Dendrochemistry of multiple releases of chlorinated solvents at a former industrial site. Environ. Sci. Technol. 46, 9541-9547.

Balouet, J.C., Smith, K.T., Vroblesky, D., Oudijk, G., 2009. Use of dendrochronology and dendrochemistry in environmental forensics: does it meet the Daubert criterial? Environ. Forensics 10, 268-276.

Broadley, M.R., White, P.J., Hammond, J.P., Zelko, I., Lux, A., 2007. Zinc in plants. New Phytol. 173, 677-702.

Carlquist, S., 2010. Comparative Wood Anatomy, second ed. Springer-Verlag, Berlin. $448 \mathrm{p}$.

Forest Products Laboratory, 1919. Potash from wood ashes. US Forest Service Forest Products Laboratory Technical Note E2. 1 p.

Janin, G., Clément, A., 1972. Mise en évidence de cristaux de carbonate de calcium dans le bois des peupliers. Ann. Sci. Forest 29, 67-105.

Janin, G. Clément, A. 1973. Étude complémentaire de la presence de cristaux de carbonate de calcium dans le bois des peupliers existence de cinq zones fonctionnelles reconnues a partir de leurs teneurs en phosphore. Ann. Sci. Forest 30, 63-81.

Krämer, U., 2010. Metal hyperaccumulation in plants. Annu. Rev. Plant Biol. 61, 517-534.

McClenahen, J.R., Vimmerstedt, J.P., Scherzer, A.J., 1989. Element concentrations in tree rings by PIXE: statistical variability, mobility, and effects of altered soil chemistry. Can. J. Forest Res. 19, 880-888.

Meerts, P., 2002. Mineral nutrient concentration in sapwood and heartwood: a literature review. Ann. Forest Sci. 59, 713-722.

Mengel, K., 2006. Potassium. In: Barker, A.V., Pilbeam, D.J. (Eds.), Handbook of Plant Nutrition. CRC Taylor \& Francis, Boca Raton, pp. 91-120.

Minocha, R., Shortle, W.C., 1993. Fast, safe, and reliable methods for extraction of major inorganic cations from small quantities of woody plant tissues. Can. J. Forest Res. 23, 1645-1654.

Momoshima, N., Bondietti, E.A., 1990. Cation binding in wood: application to understanding historical changes in divalent cation availability to red spruce. Can. J. Forest Res. 20, 1840-1849.

Ostrofsky, A., Jellison, J., Smith, K.T., Shortle, W.C., 1997. Changes in cation concentrations in red spruce wood decayed by brown rot and white rot fungi. Can. J. Forest Res. 27, 567-571.

Ostrofsky, W.D., Shortle, W.C., 1989. Applications of the Shigometer for assessing tree and forest health and wood product quality: a review. Rev. Trop. Plant Pathol. 6, 39-57.

Pearson, C.L., Dale, D., Lombardo, K., 2011. An investigation of fire scars in Pseudotsuga macrocarpa by scanning X-ray fluorescence microscopy. Forest Ecol. Manag. 262, 1258-1264.

Penninckx, V., Glineur, S., Gruber, W., Herbauts, J., Meerts, P., 2001. Radial variations in wood mineral element concentrations: a comparison of beech and pedunculate oak from the Belgian Ardennes. Ann. Forest Sci. 58, 253-260.

Pilbeam, D.J., Morley, P.S., 2006. Calcium. In: Barker, A.V., Pilbeam, D.J. (Eds.), Handbook of Plant Nutrition. CRC Taylor \& Francis, Boca Raton, pp. 121-144.

Pirkkalainen, K., Peura, M., Leppänen, K., Salmi, A., Meriläinen, A., Seranpää, P., Serimaa, R., 2012. Simultaneous X-ray diffraction and X-ray fluorescence 
microanalysis on secondary xylem of Norway spruce. Wood Sci. Technol. 46, 1113-1125.

Safford, L.O., Shigo, A.L., Ashley, M., 1974. Gradients of cation concentration in discolored and decayed wood of red maple. Can. J. Forest Res. 4, 435-440.

Shevenell, B.J., Shortle, W.C., 1986. An ion profile of wounded red maple. Phytopathology 76, 132-135.

Shigo, A.L., Hillis, W.E., 1973. Heartwood, discolored wood, and microorganisms in living trees. Annu. Rev. Phytopathol. 11, 197-222.

Shortle, W.C., 1979. Mechanisms of compartmentalization of decay in living trees. Phytopathology 69, 1147-1151.

Shortle, W.C., Smith, K.T., 1987. Electrical properties and rate of decay in spruce and fir wood. Phytopathology 77, 811-814.

Shortle, W.C., Smith, K.T., Dudzik, K.R., 1996. Decay diseases of stemwood: detection, diagnosis, and management. In: Raychaudhuri, S.P., Maramorosch, K. (Eds.), Forest Trees and Palms: Diseases and Control. Science Publishers, Lebanon, New Hampshire, pp. 95-109.

Smith, K.T., 2006. Compartmentalization today. Arboric. J. 29, 173-184.

Smith, K.T., Balouet, J.C., Oudijk, G., 2008. Elemental scanning of an increment core using EDXRF: from fundamental research to environmental forensics applications. Dendrochronologia 26, 157-163.

Smith, K.T., Houston, D.R., 1994. Metal concentrations in wood of sugar maple infected with sapstreak disease. Can. J. Forest Res. 24, 185-188.

Smith, K.T., Shortle, W.C., 1996. Tree biology and dendrochemistry. In: Dean, J.S. et al. (Eds.), Tree rings, environment and humanity. Radiocarbon, Tucson, AZ, pp. 629-635.
Smith, K.T., Shortle, W.C., Connolly, J.H., Minocha, R., Jellison, J., 2009. Calcium fertilization increases the concentration of calcium in sapwood and calcium oxalate in foliage of red spruce. Environ. Expt. Bot. 67, 277-283.

Storey, J.B., 2006. Zinc. In: Barker, A.V., Pilbeam, D.J. (Eds.), Handbook of Plant Nutrition. CRC Taylor \& Francis, Boca Raton, pp. 411-435.

Tennstedt, P., Peisker, D., Böttcher, C., Trampcynska, A., Clemens, S., 2009 Phytochelatin synthesis is essential for the detoxification of excess zinc and contributes significantly to the accumulation of zinc. Plant Physiol. 149, 938948.

Todeschini, V., Lingua, G., D’Agostino, G., Carniato, F., Roccotiello, E., Berta, G., 2011 Effects of high zinc concentration on poplar leaves: a morphological and biochemical study. Environ. Expt. Bot. 71, 50-56.

Vansteenkiste, D., Van Acker, J., Stevens, M., Le Thiec, D., Nepveu, G., 2007. Composition, distribution and supposed origin of mineral inclusions in sessile oak wood-consequences for microdensitometrical analysis. Ann. Forest Sci. 64 11-19.

Verrechia, E.P., Braissant, O., Cailleau, G., 2006. The oxalate-carbonate pathway in soil carbon storage: the role of fungi and oxalotrophic bacteria. In: Gadd, G.M (Ed.), Fungi in Biogeochemical Cycles. Cambridge University Press, New York, pp. 289-310.

Wiedenhoeft, A., 2010. Structure and function of wood, in: Ross, R.J. (Ed.), Wood Handbook. USDA Forest Service, Forest Products Laboratory General Technical Report FPL-GTR-190, pp. 1-18 (Chapter 3). 